\title{
Peertechz
}
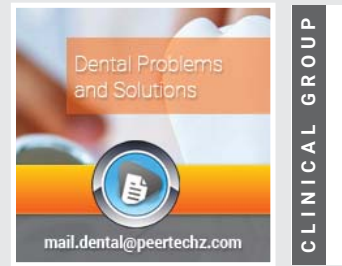

\section{Nasopharyngeal space in patients with vertical growth pattern and different anterior posterior malocclusions}

\section{Alireza Haerian', Mohammad Hossein Toodehzaeim', Elaheh Rafiei ${ }^{1}$, Firoozehsadat Aghaei ${ }^{2}$ and Pooya Fadaei Tehrani ${ }^{3 *}$}

${ }^{1}$ Assistant Professor, Department of Orthodontics, Faculty of Dentistry, Shahid Sadoughi University of Medical Sciences, Yazd, Iran

${ }^{2}$ Private Practice, Faculty of Dentistry, Shahid Sadoughi University of Medical Sciences, Yazd, Iran

${ }^{3}$ Private Practice, Dental Students Research Center, Faculty of Dentistry, Shahid Sadoughi University of Medical Sciences, Yazd, Iran
Received: 28 June, 2021

Accepted: 02 July, 2021

Published: 05 July, 2021

*Corresponding author: Dr. Pooya Fadaei Tehrani, Department of Orthodontics, Dental Students Research Center, School of Dentistry, Shahid Sadoughi University of Medical Sciences, Yazd, Iran, Tel: +989134036054. E-mail: pooya.fadaei@yahoo.com

ORCID: https://orcid.org/0000-0001-9021-9484

Keywords: Adenoid; Cephalometry; Malocclusion; Nasopharyngeal

https://www.peertechzpublications.com

\section{Check for updates}

\section{Abstract}

Introduction: There has always been debate regarding the relationship between vertical growth pattern and obstruction of the upper and lower pharyngeal airways.

Objectives: The present study was conducted to compare the dimensions of airway in cephalometric radiographs of patients with skeletal class I, II and III malocclusions, which all have a vertical growth pattern.

Methods: 66 lateral cephalometric radiographs, all of which had a vertical growth pattern, were selected, and divided into three groups (class I, II and III). The points and reference lines required to measure the area of the airway were identified. The percentage of the nasopharyngeal area occupied by the airway was calculated, and data were analyzed by SPSS version 25 software. The results were presented using ANOVA analysis of variance and multiple comparisons of Tukey HSD. The significance level was $0.05(\mathrm{P}<0.05)$

Results: The mean percentage of nasopharyngeal space occupied by the airway was $44.72 \%$ in class I, $45.58 \%$ in class II, and $49.12 \%$ in class III, but their differences were not statistically significant. Bony depth of nasopharyngeal space in class I is greater than in class II and class II greater than in class III, which had a significant difference between class I and class III (P value= 0.027). Also, the bony height of the nasopharyngeal space in class III was greater than in class I and class I greater than in class II, which was significantly different between classes II and III (P value $=0.017)$.

Conclusion: Anterior-posterior malocclusion does not affect the nasopharyngeal bone area, the adenoid area, and the airway area, as well as the percentage of the air area.

\section{Introduction}

One of the important components in the diagnostic process and treatment planning in orthodontics is the patient's respiratory function. One of the most important elements involved in respiration is the upper air spaces. The upper airway is consisted of nasopharyngeal, oropharyngeal and hypopharyngeal airways and has important functions in respiration and swallowing [1]. There is disagreement about the etiological role of adenoid hypertrophy in facial development and dental and skeletal abnormalities [2]. Normally, the adenoid in children is large and gradually degenerate with age. The large size of the adenoids increases the resistance to the flow of nasal air, and the child progresses to oral respiration [3].

According to research by Fujika, et al. [4]. The relationship between adenoid size and nasopharynx is of importance 
and is proportional to the size of adenoids and the width of the nasopharynx at fixed points. The ratio of adenoids to nasopharynx $\left(\frac{A}{N}\right)$ can be easily calculated with linear measurements of lateral cephalograms. This ratio indicates adenoids and airway openness as well as airway percentage [5]. There is a close relationship between the size of the airway space and the morphology of the face, and this space is affected by anterior functional shift, head position, anterior posterior relations, and vertical growth pattern [6]. Lateral cephalometric radiography has been used in orthodontics for many years to evaluate the growth and development of craniofacial structures, skeletal disproportions, and soft tissue [7].

With the use of cephalometry, in addition to reducing the cost and amount of radiation received by the patient, valid and repeatable information on the airway can be obtained. Various studies have shown that although measurements obtained from lateral cephalometry provide two-dimensional information, in airway assessment, it is also a reliable way to estimate adenoid size $[2,8,9]$. The size of the adenoid obtained from rhinoscopy is also related to what is seen on the lateral cephalogram [10].

Despite various studies on the subject, little research has been done on the possibility of a link between nasopharyngeal morphology and occlusal components and also facial growth and development. The question is whether the occlusion and growth and development of the face are affected by the narrowing of the nasopharyngeal space in people with normal breathing.

Studies have shown that the vertical growth pattern is associated with obstruction of the upper and lower pharyngeal airways as well as oral respiration [11-13]. Patients with class I and class II malocclusions and vertical growth patterns have significantly lower upper airway paths than those with class I and class II malocclusions and normal growth patterns [11]

Therefore, the present study aims to compare cephalometric airspace in Class I, II and III skeletal malocclusions, all of which have a vertical growth pattern. Because linear measurement of the soft tissue of the nasopharyngeal space is not reliable [14], measuring the area of the nasopharyngeal space can be helpful. Therefore, in this study, in addition to linear measurement of nasopharyngeal space, nasopharyngeal area and airway area as well as airway percentage were studied.

\section{Methods}

This study was approved by the Ethics in Research Committee under control number IR.SSU.REC.1395.159. Sampling was done by simple random sampling method and considering the significance level of $5 \%$ and test power of $80 \%$, 22 people in each group and a total of 66 people were required. The cephalometric radiographs of 66 patients aged between 8 and18 years who were referred to the orthodontic department of the School of Dentistry, were examined. The samples all had a vertical growth pattern. This age range was chosen because the maxillary bone growth was complete, and the size of the adenoid ranged from the largest to the smallest among the samples. Conditions for entering the study included: no oral respiration, no nocturnal snoring, no history of adenoid removal, no oral habits, no history of facial fractures, no history of orthodontic treatment and corrective orthognathic surgery, the absence of temporomandibular joint disease and the absence of various syndromes.

Radiographs with standard conditions (resting lips, teeth in occlusion, and natural head position) were selected, which also had sufficient clarity. Also, the conditions for excluding the samples from the study were: lack of clarity and quality of radiographs and incompleteness of patients' files.

\section{Cephalometric analysis}

The dimensions of the pharyngeal space were measured on all radiographs (Figure 1). The vertical growth pattern of the samples was selected based on FMA, GoGn-Sn angles and Jarabak Index. The samples were divided into three groups based on ANB angle [15]:

Group A: Class I malocclusion (ANB $1^{\circ}-4^{\circ}$ )

Group B: Class II malocclusion (ANB $\left.>4^{\circ}\right)$

Group C: Class III malocclusion $\left(\mathrm{ANB}<1^{\circ}\right)$

The Wits index was also used to determine the type of antero-posterior occlusion. The number of samples in each

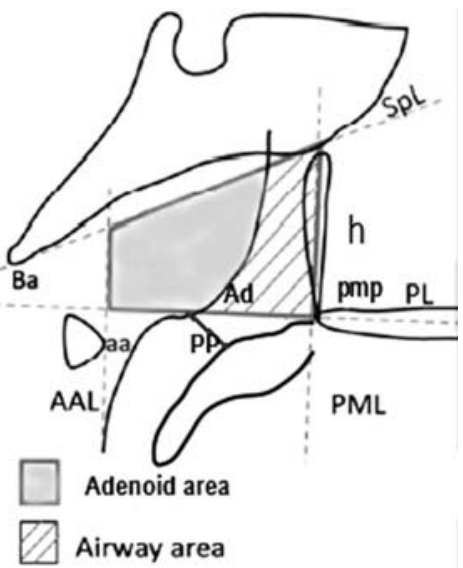

Figure 1: Nasopharyngeal space variables.

Nasopharyngeal (NP) area: The bony area of the nasopharyngeal space.

Height (h): The anterior bony height of the nasopharyngeal space.

Air area: The airway area of the nasopharyngeal space (the difference between NP area and Adenoid area)

Adenoid area: The area occupied by the adenoid gland.

Air area\%: Percentage of pharyngeal nasal space occupied by the airway.

Ad (Adenoid): The point of junction between Ba-PMP and the anterior portion of

the posterior nasopharyngeal space's soft tissue.

PMP (Petrygomaxillary Palatinume): The point of junction between the bony palate and the Pterygomaxillary fissure.

AAL (Anterior atlas line): A line perpendicular to the Palatal line from the anterior atlas (AA) point

PL (Palatal Line): The line connecting Anterior Nasal Spine (ANS) and PMP points. Ba-PMP: The bony depth of the nasopharyngeal space.

Ad-PMP: The depth of the airway of the nasopharyngeal space. PP: The palatopharyngeal depth of Nasopharyngeal airway.

PMP distance to the point of intersection of PL and AAL planes: Nasopharyngea bone depth

Citation: Haerian A, Toodehzaeim MH, Rafiei E, Aghaei F, Tehrani PF (2021) Nasopharyngeal space in patients with vertical growth pattern and different anterior posterior malocclusions. J Dent Probl Solut 8(2): 047-051. DOI: https://dx.doi.org/10.17352/2394-8418.000104 
group was 22 and the radiographs were matched in terms of age and sex. The points and reference lines required to measure the pharyngeal space was also identified. Radiographs were scanned under equal conditions and measured and summarized by the AutoCAD software (Autodesk, San Rafael, CA). The nasopharyngeal space bone area, the nasopharyngeal airway area, and the nasopharyngeal space bone depth were measured according to Figure 2. Afterwards, the percentage of airway area in each of the samples was obtained, the area of airway and its percentage was compared in each group of samples, and finally, the relationship between pharyngeal nasal space and different malocclusions were determined.

Statistical analyzes were performed by SPSS version 25 (SPSS Incorporation, Chicago, USA). The results were presented using ANOVA analysis of variance and multiple comparisons of Tukey HSD. Level of significance was set at 0.05 .

\section{Results}

The variables measured in the present study are presented in Tables 1,2. The results of the ANOVA test showed that there were no significant statistical differences between the different study groups in terms of PMP to the point of intersection of PL and ALL, Ad-PMP, PP, NP area, Adenoid area, Air area and Air area\%.

The Ba-PMP and Height variables had a significant difference between the groups, so that the Ba-PMP variable in class I was greater than class II and class II greater than class III. The Height variable in class III was greater than class I and class I was greater than class II. The Tukey test was performed for these two statistically significant variables. The results of this test are given in Table 3.

According to the ANOVA test and Table 2, the differences observed in the PMP to the point of intersection of the PL and AAL planes, NP area, Ad-PMP, Adenoid area, Air area and Air area $\%$ were not statistically significant $(\mathrm{P}>0.05)$.
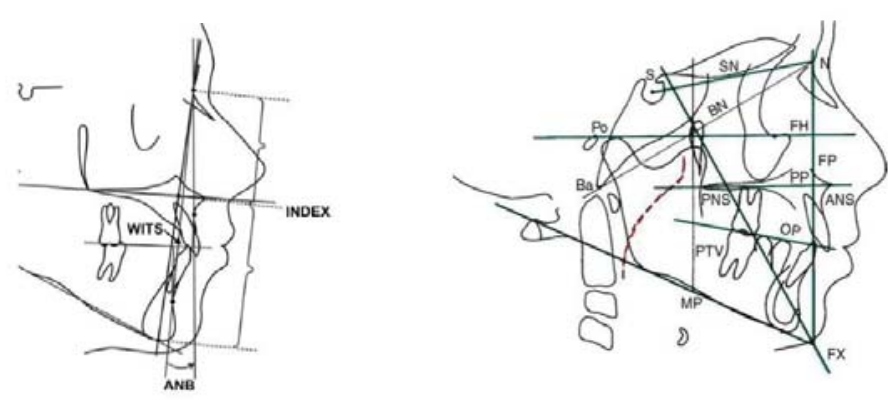

Figure 2: Reference points, reference lines and measurements used for lateral cephalometric analysis.

ANB: The angle between the intersection of the NB and NA lines.

FMA: Angle between Mandibular Plane and Frankfort Line.

GoGn-Sn: Angle between GoGn and Sn planes.

Wits: The millimeter distance between lines perpendicular to points A and B on the

occlusal plane.

Jarabak Index: The posterior height of the face divided by the anterior height of the face $\left(\frac{S-G o}{N-G e}\right.$
Table 1: Sample characteristics.

\begin{tabular}{|c|c|c|c|c|c|c|}
\hline $\begin{array}{c}\text { Variables } \\
\text { Study Groups }\end{array}$ & $\begin{array}{c}\text { Age } \\
\text { (Years) }\end{array}$ & $\begin{array}{c}\text { FMA } \\
\text { (Degree) }\end{array}$ & $\begin{array}{c}\text { GoGn-Sn } \\
\text { (Degree) }\end{array}$ & $\begin{array}{c}\text { Jarabak index } \\
\text { (Percentage) }\end{array}$ & $\begin{array}{c}\text { ANB } \\
\text { (Degree) }\end{array}$ & $\begin{array}{c}\text { Wits } \\
\text { (mm) }\end{array}$ \\
\hline $\begin{array}{c}\text { Group A } \\
(n=22)\end{array}$ & 12.77 & 29 & 37.09 & 59.08 & 2.25 & -0.36 \\
\hline $\begin{array}{c}\text { Group B } \\
(n=22)\end{array}$ & 12.86 & 31.36 & 38.59 & 59.10 & 6.39 & 3.64 \\
\hline $\begin{array}{c}\text { Group C } \\
(n=22)\end{array}$ & 13.18 & 33.09 & 40.40 & 58.46 & 0.27 & -5.34 \\
\hline
\end{tabular}

*P-value $<0.05$

Group A: Class I skeletal malocclusion, Group B: Class II skeletal malocclusion, Group C: Class III skeletal malocclusion

Table 2: Comparison of the means and standard deviations of nasopharyngeal space variables.

\begin{tabular}{|c|c|c|c|c|}
\hline $\begin{array}{c}\text { Study } \\
\text { Groups } \\
\text { Variables }\end{array}$ & $\begin{array}{c}\text { Group A } \\
(n=22) \\
\text { Mean } \pm S D\end{array}$ & $\begin{array}{c}\text { Group B } \\
(n=22) \\
\text { Mean } \pm S D\end{array}$ & $\begin{array}{c}\text { Group C } \\
(n=22) \\
\text { Mean } \pm S D\end{array}$ & P-value \\
\hline NP area & $537.1 \pm 124.8$ & $524.78 \pm 123.59$ & $530.6 \pm 120.76$ & 0.061 \\
\hline Adenoid area & $303.96 \pm 121$ & $278.42 \pm 107.8$ & $265.72 \pm 131.2$ & 0.504 \\
\hline Air area & $234.18 \pm 69.67$ & $244.09 \pm 117.39$ & $265.18 \pm 131.19$ & 0.623 \\
\hline Air area\% & $44.72 \pm 12.37$ & $45.58 \pm 17.24$ & $49.12 \pm 18.11$ & 0.634 \\
\hline Ba-PMP & $40.89 \pm 3.31$ & $39.78 \pm 4.68$ & $37.13 \pm 3.57$ & $0.032^{\star}$ \\
\hline $\begin{array}{l}\text { PMP to the } \\
\text { intersection of } \mathrm{PL} \\
\text { and } \mathrm{AAL} \text { plans }\end{array}$ & $28.92 \pm 4.7$ & $28.52 \pm 3.86$ & $28.17 \pm 4.52$ & 0.847 \\
\hline Height & $27.3 \pm 4.54$ & $26.46 \pm 4.62$ & $30.2 \pm 3.74$ & $0.017^{*}$ \\
\hline Ad-PMP & $19.2 \pm 3.43$ & $19.3 \pm 5.99$ & $18.96 \pm 4.96$ & 0.974 \\
\hline PP & $9.56 \pm 5.04$ & $9.96 \pm 4.56$ & $10.31 \pm 5.04$ & 0.876 \\
\hline
\end{tabular}

*P-value $<0.05$

Group A: Class I skeletal malocclusion, Group B: Class II skeletal malocclusion,

Group C: Class III skeletal malocclusion

Table 3: Comparison of nasopharyngeal space variables between study groups

\begin{tabular}{|c|c|c|c|c|c|c|c|}
\hline \multirow{2}{*}{$\begin{array}{c}\text { Study Groups } \\
\text { Variables } \\
\text { NP area }\end{array}$} & \multicolumn{2}{|c|}{$\begin{array}{c}\text { Group A } \\
(n=22) \text { Mean } \pm S D\end{array}$} & \multicolumn{2}{|c|}{$\begin{array}{c}\text { Group B } \\
(n=22) \text { Mean } \pm S D\end{array}$} & \multicolumn{2}{|c|}{$\begin{array}{c}\text { Group C } \\
(n=22) \text { Mean } \pm S D\end{array}$} & \multirow{2}{*}{\begin{tabular}{|c|} 
P-value \\
NS \\
\end{tabular}} \\
\hline & $537.1 \pm 124.8$ & a & $524.78 \pm 123.59$ & a & $530.6 \pm 120.76$ & a & \\
\hline Aden & 303 & a & & a & & a & NS \\
\hline & (20) & a & 39 & $\mathrm{a}$ & 9 & a & NS \\
\hline Air & $44.12 \pm 12.01$ & a & $40.50 \pm 11.24$ & $a$ & 49.121 & $d$ & $\cdots$ \\
\hline Ba-PIVIP & 4 & $a, b$ & 3 & & 7. & C & 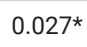 \\
\hline $\begin{array}{c}\text { PMP to the } \\
\text { intersection } \\
\text { of PL and AAL } \\
\text { planes }\end{array}$ & $28.92 \pm 4.7$ & a & 28.5 & a & 28.1 & a & NS \\
\hline Height & $27.3 \pm 4.54$ & $a, D$ & $26.46 \pm 4.62$ & a & $30.2 \pm 3.74$ & $c, b$ & 0.01 \\
\hline Ad-PMP & $19.2 \pm 3.43$ & a & $19.3 \pm 5.99$ & a & $18.96 \pm 4.96$ & a & NS \\
\hline & $9.56 \pm 5.04$ & a & $96 \pm 4.56$ & a & $0.31 \pm 5.04$ & a & \\
\hline
\end{tabular}

NS $=$ Non-Significant

Means with similar letters in each row do not have a significant difference.

*The level of significance of the groups with significant differences is mentioned (P-value < 0.05).

Group A: Class I skeletal malocclusion, Group B: Class II skeletal malocclusion, Group C: Class III skeletal malocclusion

\section{Discussion}

One of the most challenging issues in orthodontics is the relationship between airway and face morphology. Many studies have examined this relationship, and each has used

Citation: Haerian A, Toodehzaeim MH, Rafiei E, Aghaei F, Tehrani PF (2021) Nasopharyngeal space in patients with vertical growth pattern and different anterior posterior malocclusions. J Dent Probl Solut 8(2): 047-051. DOI: https://dx.doi.org/10.17352/2394-8418.000104 
different methods to examine the dimensions of airway [16-18]. Since diagnostic records can be used before routine orthodontic treatment and thus avoid giving the patient an additional dose of radiation $[19,20]$, lateral cephalometry radiography was used in this study. Studies have shown that the use of lateral cephalometry to measure the nasopharyngeal area is quite valid [21, 22]. Also, Aboudara, et al. [23] Compared the lateral cephalometry and СBCT radiographs in the airway assessment and found that the lateral cephalometry provided a good indicator of the openness of the nasopharyngeal airway. Since the vertical growth pattern has the greatest impact on the dimensions of the airway [11,24-26], in the present study, all samples were patients with a vertical growth pattern.

Among the variables measured in the present study, the two variables of nasopharyngeal bony depth and anterior height of nasopharyngeal space were significantly different between groups, while the bony depth of nasopharyngeal space was smaller in skeletal class III group and its height was greater in skeletal class III group.

Islamian, et al. [26] Showed that malocclusions in the sagittal plane could affect the depth of the nasopharyngeal space, so that in class III patients this depth is lower. Such a finding seems to be due to the greater posterior position of the maxilla in class III patients.

The other measured variables did not differ significantly between different groups. In a study, Ceylan, et al. [27] Examined the nasopharyngeal area and concluded that the variable was not affected by sagittal malocclusions, stating that the oropharyngeal space was more affected by anteriorposterior malocclusion. They also showed that the anterior height of the nasopharyngeal area in class II was more than class I and in class I more than class III, but this variable was not significant in their study. In the same study, the depth of the nasopharyngeal area (Ba-PNS) was examined, which was higher in class II compared to class III and higher in class III compared to class I, but this difference was not significant in their study. The reason for the difference between the results of the present study and the study of Ceylan et al. can be the number of samples and that our study was only on the vertical growth pattern.

Freits, et al. [11] And Sosa, et al. [28], found similar results with our study, stating that the width of nasopharyngeal area is not affected by sagittal malocclusion. Memon, et al. [12], using Mc Namara's analysis to assess airway dimensions, concluded that sagittal malocclusion did not affect the width of the upper pharyngeal region. In the present study, the airway depth of the nasopharyngeal region did not show a significant difference between the study groups.

In a study of the depth of the nasopharyngeal airway, Zhong, et al. [29] found similar results and concluded that the dimensions of the upper airway were not affected by sagittal malocclusion, but that sagittal malocclusions had a greater effect on hypopharyngeal and palatopharyngeal dimensions, so that in class III patients, these dimensions are larger.
Another variable that was not affected by sagittal malocclusion was the anterior-posterior bony depth of the nasopharyngeal area. Tourne, et al. [30] And Handleman and Osborne [31] found similar results, stating that the depth is stabilized at an early age and usually remained the same. For this reason, sagittal malocclusion may not affect the anteriorposterior bony depth of the nasopharyngeal area.

\section{Conclusion}

This study showed that in patients with a vertical growth pattern, there was no significant difference between nasopharyngeal area, airway area and adenoid area, as well as the percentage of airway between different anterior-posterior malocclusions and that, anterior-posterior malocclusion does not affect the nasopharyngeal bony area, the adenoid area, and the airway area, as well as the percentage of airway. However, anterior-posterior malocclusion may affect the nasopharyngeal depth (Ba-PMP) and its height.

\section{Acknowledgments}

The authors gratefully acknowledge that this report is based on a thesis which was submitted to the School of Dentistry, XXXXXX University of Medical Sciences, in partial fulfillment of the requirement for the DDS degree. (\#792) This study supported and approved by Vice Chancellor for Research at XXXXXXX University of Medical Science.

\section{References}

1. El H, Palomo JM (2011) Airway volume for different dentofacial skeletal patterns. Am J Orthod Dentofacial Orthop 139: e511- e521. Link: https://bit.ly/3AorSEA

2. Koca CF, Erdem T, Bayındır T (2016) The effect of adenoid hypertrophy on maxillofacial development: an objective photographic analysis. J Otolaryngol Head Neck Surg 45: 48. Link: https://bit.ly/3hfPm6Y

3. Ysunza A, Pamplona MC, Ortega JM, Prado H (2008) Video fluoroscopy for evaluating adenoid hypertrophy in children. Int $\mathrm{J}$ of Pediatr Otorhinolaryngo 72: 1159-1165. Link: https://bit.ly/3wgxD3A

4. Fujioka M, Young LW, Girdany BR (1979) Radiographic evaluation of adenoidal size in children: adenoidal-nasopharyngeal ratio. AJR Am J Roentgenol 133 401-404. Link: https://bit.ly/3Ao5aw2

5. Talebian S, Sharifzadeh G, Vakili I, Golboie SH (208) Comparison of adenoid size in lateral radiographic, pathologic, and endoscopic measurements. Electron physician 10: 6935-6941. Link: https://bit.ly/3wdX2LA

6. Ucar Fl, Uysal T (2011) Orofacial airway dimensions in subjects with Class I malocclusion and different growth patterns. Angle Orthod 81:460-468. Link: https://bit.ly/368J6Ym

7. Samman N, Mohammadi H, Xia J (2003) Cephalometric norms for the upper airway in a healthy Hong Kong Chinese population. Hong Kong Med J 9: 25-30. Link: https://bit.ly/3xfB4cl

8. Oulis CJ, Vadiakas GP, Ekonomides J, Dratsa J (1994) The effect of hypertrophic adenoids and tonsils on the development of posterior crossbite and oral habits. J Clin Pediatr Dent 18: 197-201. Link: https://bit.ly/3hu4RqT

9. Muto T, Yamazaki A, Takeda S (2008) A cephalometric evaluation of the pharyngeal airway space in patients with mandibular retrognathia and prognathia, and normal subjects. Int J Oral Maxillofac Surg 37: 228-231. Link: https://bit.ly/2Tu0nIQ 
10. Fujioka M, Young LW, Girdany BR (1979) Radiographic evaluation of adenoidal size in children: adenoidal-nasopharyngeal ratio. AJR Am J Roentgenol 133: 401-404. Link: https://bit.ly/3Ao5aw2

11. de Freitas MR, Alcazar NM, Janson G, de Freitas KM, Henriques JF (2006) Upper and lower pharyngeal airways in subjects with Class I and Class II malocclusions and different growth patterns. Am J Orthod Dentofacial Orthop 130: 742-745. Link: https://bit.ly/3hyFtQO

12. Memon S, Fida M, Shaikh A (2012) Comparison of different craniofacial patterns with pharyngeal widths. J Coll Physicians Surg Pak 22: 302-306. Link: https://bit.ly/3dFxUXp

13. Nunes WR, Di Francesco RC (2010) Variation of patterns of malocclusion by site of pharyngeal obstruction in children. Arch Otolaryngol Head Neck Surg 136: 1116-1120. Link: https://bit.ly/3hc1hCN

14. Martin O, Muelas L, Viñas MJ (2006) Nasopharyngeal cephalometric study of ideal occlusions. Am J Orthod Dentofacial Orthop 130: 436.e1-9. Link: https://bit.ly/36ajLNU

15. Yagci A, Veli I, Uysal T, Ucar FI, Ozer T, et al. (2012) Dehiscence and fenestration in skeletal Class I, II, and III malocclusions assessed with cone-beam computed tomography. Angle Orthod 82: 67-74. Link: https://bit.ly/2TvrMKA

16. Grauer D, Cevidanes LS, Styner MA, Ackerman JL, Proffit WR (2009) Pharyngeal airway volume and shape from cone-beam computed tomography: relationship to facial morphology. Am J Orthod Dentofacial Orthop 136: 805814. Link: https://bit.ly/3jlpMJB

17. Shokri A, Miresmaeili A, Ahmadi A, Amini P, Falah-Kooshki S (2018) Comparison of pharyngeal airway volume in different skeletal facial patterns using cone beam computed tomography. J Clin Exp Dent 10: e1017- e1028. Link: https://bit.ly/2TzJaOF

18. Claudino LV, Mattos CT, Ruellas AC, Sant' Anna EF (2013) Pharyngea airway characterization in adolescents related to facial skeletal pattern: a preliminary study. Am J Orthod Dentofacial Orthop 143: 799-809. Link: https://bit.ly/36oGHcx

19. Nijkamp PG, Habets LL, Aartman IH, Zentner A (2008) The influence of cephalometrics on orthodontic treatment planning. Eur J Orthod 30: 630-635. Link: https://bit.ly/36eU7Y8

20. Stupar I, Yetkiner E, Wiedemeier D, Attin T, Attin R (2018) Influence of Lateral Cephalometric Radiographs on Orthodontic Treatment Planning of Class II Patients. Open Dent J 12: 296-302. Link: https://bit.ly/36ajWZA

21. Pirilä-Parkkinen $K$, Löppönen $H$, Nieminen $P$, Tolonen U, Pääkkö $E$, et al. (2011) Validity of upper airway assessment in children: a clinical, cephalometric, and MRI study. Angle Orthod 81: 433-439. Link: https://bit.ly/3wfba7l

22. Retcheski AJ Silva NP, Leite F, Nouer PR (2014) Reliability of adenoid hypertrophy diagnosis by cephalometric radiography. Rev Gaucha Odontol 62 : 275-280. Link: https://bit.ly/3he3qOp

23. Aboudara C, Nielsen I, Huang JC, Maki K, Miller AJ, et al. (2009) Comparison of airway space with conventional lateral headfilms and 3-dimensional reconstruction from cone-beam computed tomography. Am J Orthod Dentofacial Orthop 135: 468-479. Link: https://bit.ly/3jDrrA9

24. Wang T, Yang Z, Yang F, Zhang M, Zhao J, et al. (2014) A three dimensiona study of upper airway in adult skeletal Class II patients with different vertical growth patterns. PLoS One 9: e95544. Link: https://bit.ly/3Ao7t2a

25. Tarkar JS, Parashar S, Gupta G, Bhardwaj P, Maurya RK, et al. (2016) An Evaluation of Upper and Lower Pharyngeal Airway Width, Tongue Posture and Hyoid Bone Position in Subjects with
Different Growth Patterns. J Clin Diagn Res 10: ZC79- ZC83. Link: https://bit.ly/2Uf15d7

26. Eslamian L, Badiee MR, Yousefinia S, Kharazifard MJ (2014) Radiographic Assessment of Upper Airway Size in Skeletal Sagittal and Vertical Jaw Discrepancies. J Islam Dent Assoc Iran 26: 96-101. Link: https://bit.ly/3qH1945

27. Ceylan I, Oktay H (1995) A study on the pharyngeal size in different skeletal patterns. Am J Orthod Dentofacial Orthop 108: 69-75. Link: https://bit.ly/2UY1i4F

28. Sosa FA, Graber TM, Muller TP (1982) Postpharyngeal lymphoid tissue in Angle Class I and Class II malocclusions. Am J Orthod 81: 299-309. Link: https://bit.ly/3dE4kSg

29. Zhong Z, Tang Z, Gao X, Zeng XL (2010) A comparison study of upper airway among different skeletal craniofacial patterns in nonsnoring Chinese children. Angle Orthod 80: 267-274. Link:https://bit.ly/2TvJnSG

30. Tourné LP (1991) Growth of the pharynx and its physiologic implications. Am J Orthod Dentofacial Orthop 99: 129-139. Link: https://bit.ly/3yj96fT

31. Handelman CS, Osborne G (1976) Growth of the nasopharynx and adenoid development from one to eighteen years. Angle Orthod 46: 243-259. Link: https://bit.ly/3dDGOVy

\section{Discover a bigger Impact and Visibility of your article publication with}

\section{Peertechz Publications}

\section{Highlights}

* Signatory publisher of ORCID

* Signatory Publisher of DORA (San Francisco Declaration on Research Assessment)

- Articles archived in worlds' renowned service providers such as Portico, CNKI, AGRIS TDNet, Base (Bielefeld University Library), CrossRef, Scilit, J-Gate etc.

* Journals indexed in ICMJE, SHERPA/ROMEO, Google Scholar etc.

* OAI-PMH (Open Archives Initiative Protocol for Metadata Harvesting)

* Dedicated Editorial Board for every journal

* Accurate and rapid peer-review process

* Increased citations of published articles through promotions

* Reduced timeline for article publication

Submit your articles and experience a new surge in publication services (https://www.peertechz.com/submission).

Peertechz journals wishes everlasting success in your every endeavours.

Copyright: @ 2021 Haerian A, et al. This is an open-access article distributed under the terms of the Creative Commons Attribution License, which permits unrestricted use, distribution, and reproduction in any medium, provided the original author and source are credited.

Citation: Haerian A, Toodehzaeim MH, Rafiei E, Aghaei F, Tehrani PF (2021) Nasopharyngeal space in patients with vertical growth pattern and different anterior posterior malocclusions. J Dent Probl Solut 8(2): 047-051. DOI: https://dx.doi.org/10.17352/2394-8418.000104 